\title{
The impact of supportive nursing care on the needs of men with prostate cancer: a study across seven European countries
}

\author{
J Cockle-Hearne ${ }^{1}$, F Charnay-Sonnek ${ }^{2}$, L Denis ${ }^{3}$, H E Fairbanks ${ }^{4}$, D Kelly ${ }^{5}$, S Kav ${ }^{6}$, K Leonard $^{7}$, \\ E van Muilekom ${ }^{8}$, P Fernandez-Ortega ${ }^{9}$, B T Jensen ${ }^{10}$ and S Faithfull ${ }^{\star, 1}$

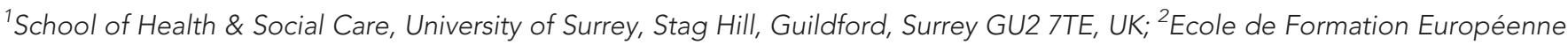 \\ en Cancérologie, Paris, France; ${ }^{3}$ Oncology Centre, Antwerp, Belgium; ${ }^{4}$ University of Reading, Statistical Services Centre, Harry Pitt \\ Building, Whiteknights Road, Reading, RG6 6FN, UK; ${ }^{5}$ School of Nursing and Midwifery Studies, University of Cardiff, Wales, UK; \\ ${ }^{6}$ Basknet University, Faculty of Health Sciences, Department of Nursing, Baglica, Kampusu, Ankara, Turkey; ${ }^{7}$ St Luke's Radiation \\ Oncology Centre, St James's Hospital, James Street, Dublin 8, Ireland; ${ }^{8}$ Netherlands Cancer Institute, Amsterdam, The \\ Netherlands; ${ }^{9}$ Institute Catala d'Oncologica-Hospital Durani i Reynals, Barcelona University, Barcelona, Spain and ${ }^{10}$ Aarhus \\ University Hospital, Aarhus, Denmark
}

Background: Prostate cancer is for many men a chronic disease with a long life expectancy after treatment. The impact of prostate cancer therapy on men has been well defined, however, explanation of the consequences of cancer treatment has not been modelled against the wider variables of long-term health-care provision. The aim of this study was to explore the parameters of unmet supportive care needs in men with prostate cancer in relation to the experience of nursing care.

Methods: A survey was conducted among a volunteer sample of 1001 men with prostate cancer living in seven European countries.

Results: At the time of the survey, $81 \%$ of the men had some unmet supportive care needs including psychological, sexual and health system and information needs. Logistic regression indicated that lack of post-treatment nursing care significantly predicted unmet need. Critically, men's contact with nurses and/or receipt of advice and support from nurses, for several different aspects of nursing care significantly had an impact on men's outcomes.

Conclusion: Unmet need is related not only to disease and treatment factors but is also associated with the supportive care men received. Imperative to improving men's treatment outcomes is to also consider the access to nursing and the components of supportive care provided, especially after therapy.

Prostate cancer is a significant health burden within Europe with recent survival data suggesting that the number of men with this disease will increase over the next 20 years (Berrino et al, 2007; Siegel et al, 2012). Prostate cancer is being detected earlier, and as a consequence more men receive treatment and subsequently face adverse effects of therapy (Resnick et al, 2013b). Despite improvements to cancer treatment, some men will continue to experience long-term consequences. Population-based studies have highlighted that prostate cancer survivors report significant chronic illness compared with age-matched controls, with poorer health status and reduced quality-of-life (Van Hemelrijck et al, 2010; Elliott et al, 2011; Khan et al, 2011; Higano, 2012; Lustberg et al, 2012). Increasingly, there is recognition that lifestyle factors correlate with the risk of late pelvic symptoms after prostate cancer treatment (Thomas et al, 2013) and can have an impact on men's overall survival (Kenfield et al, 2011).

*Correspondence: Professor S Faithfull; E-mail: s.faithfull@surrey.ac.uk

Received 15 May 2013; revised 12 August 2013; accepted 26 August 2013;

published online 24 September 2013

(c) 2013 Cancer Research UK. All rights reserved 0007-0920/13

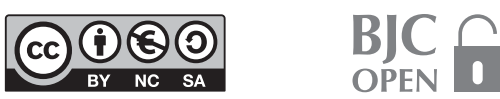


Such survivorship results in an enduring requirement for healthcare monitoring and challenges providers of cancer care to effectively respond to men's long-term supportive care needs (Simonelli et al, 2008; Harrison et al, 2009; McCabe et al, 2011). Critical to health service planning is the need to recognise the factors that contribute to men's poorer health and the ability to identify what supportive care packages, such as nursing, are needed and at what time in the treatment and recovery pathway.

Although studies of prostate cancer often focus on functional outcomes of therapy, the extent to which adverse effects bother men also needs careful evaluation (Luckett et al, 2009; Pachman et al, 2012; Seklehner et al, 2012). Understanding the importance of comprehensive patient outcomes is essential in delivering wholepatient cancer care (Jacobsen et al, 2012; Stanton, 2012). Studies exploring unmet needs of men with prostate cancer consistently show that these needs are highest in relation to psychological and sexuality issues, as well as information about treatment and care in the health-care setting (Steginga et al, 2001; Boberg et al, 2003; White et al, 2012). Several predictive analyses from unmet needs studies have found significant associations between unmet need and factors of age, education, marital status, treatment variables, disease characteristics and mental affect (Smith et al, 2007; Ream et al, 2008). None of these studies have explored unmet need against the type or nature of supportive care these men received. Identifying the characteristics of unmet need and nursing outcomes over the cancer pathway can contribute to the evidence of the impact of specialist nurses as well as clarify quality parameters in providing good after-care. In this study, we examine the relative predictive impact of prostate-specific dimensions of nursing care on the scope and extent of men's unmet supportive care needs across seven countries within Europe.

\section{MATERIALS AND METHODS}

We surveyed men with a diagnosis of prostate cancer living in Denmark, France, Ireland, Netherlands, Spain, Turkey and the UK via on-line and paper questionnaire. Pre-survey information, together with the on-line link, was posted on support group, charity and nursing organisation websites, and leaflets were distributed through support networks and clinic settings. The questionnaire was translated and the response was anonymous. The survey was available on-line for one month in October/ November 2011 during which time 1131 eligible men started the questionnaire and 558 (49\%) completed. Between October 2011 and early January 2012, 2111 paper questionnaires were also made available to centres for use where paper completion was preferred (numbers of questionnaires distributed within the individual countries were not recorded). A total of 443 (21\%) completed paper questionnaires were returned to the United Kingdom. Consent information was given within the survey before the start of both on-line and paper questionnaire and consent was indicated by commencement of the survey.

Three patient-reported outcome scales were included in the questionnaire.

The Supportive Care Needs Survey (SCNS) is a valid and reliable 34-item tool for assessing cancer patients' unmet needs. It assesses five domains: psychological; sexuality; health system and information; physical and daily activity and patient care and support (Boyes et al, 2009). Need for help is rated on a five-point scale: $1=$ not applicable, $2=$ satisfied, $3=$ low need, $4=$ moderate need and $5=$ severe need. Five items from the SCNS prostatespecific module were also used related to urinary function, bowel function and hormonal effects.

The EuroQol EQ-5D-3L is a standardised, valid and reliable measure of health status for clinical and economic use (Pickard et al, 2007). It measures five dimensions: mobility, self-care, usual activities, pain/discomfort and anxiety/depression. Each is scored on a three-point scale representing no problem, some problem and extreme problem. A self-rating scale of Health State is scored from $0-100$ on a visual scale, 0 representing the 'worst imaginable health state' and 100 representing the 'best imaginable health state'.

Experience of supportive nursing care was measured using a scale developed by the authors. It contained nine dimensions of supportive care commonly provided by hospital nurses (see column 1 in Table 4). The items were developed based on research literature utilising evidence from specialist nursing domains (Eicher et al, 2012) and clinician and patient consultation in each of the seven countries. Response was measured on a fourpoint scale by participants indicating for each dimension if they strongly agreed, agreed, disagreed or strongly disagreed that they had received advice and support. If they had not seen a nurse at all for that dimension of care, they were asked to check a fifth column. These questions aimed to provide patient-reported data for nursing provision and covered supportive care across the disease journey.

We also collected demographic characteristics (age, education, living status, ethnicity and country of residence), and disease and treatment characteristics (time since diagnosis, treatment modality, time since treatment, time last assessed by a clinician and stage of disease).

We hypothesised that demographic and treatment characteristics, patient-reported outcomes of quality-of-life (mental affect and health state) and patient experience would be associated with unmet needs of men with prostate cancer. Descriptive analysis examined sample characteristics and patient-reported outcome measures. Analysis for SCNS domains was conducted on an overall response of no need (all item responses of not applicable or satisfied) vs some need (at least one item response of low, moderate or high unmet need). Within each domain, missing item responses were imputed using multiple imputations (Markov Chain Monte Carlow method) in IBM SPSS Statistics version 19.0 (London, UK).

Predictive modelling for some need was developed using the backwards elimination selection procedure to identify suitable logistic regression models for each of the five domains based on the pooled model results. Where possible, interactions were included in the models but none were found to be significant. All testing was conducted at the 5\% significance level. Covariates incorporated into the models included known predictors of need from other published studies: age, country of residence, education, living status, stage of disease, time since diagnosis, time since last assessed, treatment modality, treatment status nested within treatment degree, mental affect (measured by the EuroQol item on depression and anxiety) and health state (Table 1). Nine variables relating to supportive nursing care across the disease journey were introduced to the final analysis to assess whether men's experience of nursing care could explain any variation over and above that explained by the initial models. Backwards elimination was used to remove non-significant terms. The resulting final models were all statistically significant $P<0.001$ for all domains. The Youden indices ranged from 0.316 to 0.564 . Sensitivity and specificity were higher comparing the models with nursing care variables to the initial models for the psychological, health system and information and the patient care and support domains.

\section{RESULTS}

Study participants. Data was based on 1001 complete questionnaires. The majority of participants were aged between $61-80$, of white ethnic origin and living with others, and there were similar 


\begin{tabular}{|c|c|}
\hline Variable & Definition \\
\hline $\begin{array}{l}\text { Treatment } \\
\text { modality }\end{array}$ & $\begin{array}{l}\text { Created for all separate treatments received, defined as } \\
\text { not had treatment vs received/currently receiving } \\
\text { treatment }\end{array}$ \\
\hline $\begin{array}{l}\text { Treatment } \\
\text { degree }\end{array}$ & $\begin{array}{l}\text { Considering treatment or monitoring vs had a single } \\
\text { treatment modality vs had multiple treatment modalities }\end{array}$ \\
\hline $\begin{array}{l}\text { Treatment } \\
\text { status }\end{array}$ & $\begin{array}{l}\text { Considering treatment or monitoring vs currently } \\
\text { on-treatment vs finished treatment }<1 \text { year ago vs } \\
\text { finished treatment more than } 1 \text { year ago }\end{array}$ \\
\hline Mental affect & $\begin{array}{l}\text { Derived from the EuroQoL EQ-5D anxiety/depression } \\
\text { dimension, where a response of not anxious or } \\
\text { depressed }=0 \text { and moderately or extremely } \\
\text { depressed }=1\end{array}$ \\
\hline Health state & $\begin{array}{l}\text { A continuous variable represented by participant } \\
\text { rating on the EuroQoL EQ-5D VAS scale }\end{array}$ \\
\hline
\end{tabular}

numbers of men in each of the education categories (Table 2). Over one-quarter of the sample had been diagnosed within the last year, and one-quarter 1 and 2 years previously. A total of $36.9 \%$ of men were receiving treatment at the time of the survey, $20.5 \%$ were $<1$ year out of treatment and $40.4 \%$ were $\geqslant 1$ year out of treatment; few were considering treatment. Equal numbers of men had received radical prostatectomy, radiotherapy or hormone therapy $(43.6 \% /$ $44.6 \% / 43.8 \%)$, fewer men had experience of active surveillance (16.2\%) and watchful waiting (12.2\%), $57.7 \%$ of men had received multiple treatments. Moderate or extreme anxiety or depression (mental affect) was reported by $33.7 \%$ of men: normative data are only available in three countries (Netherlands, Spain and the United Kingdom) indicating percentage ranges for men over 40 years of age to be 18 $33 \%, 7-20 \%$ and $16-26 \%$, respectively (Svende and Williams, 2004) and mental affect measured by the EQ-5D for men with prostate cancer in the United Kingdom has been reported at 30\% (Ream et al, 2008). Mean self-rating for health state was 74.3 (s.d. 17.6 median 80 , 65/90) (Table 2): normative data for men in Netherlands, Spain and the United Kingdom indicate mean ranges across age groups for men over 40 years of age to be $69-82,67-78$ and $71-85$, respectively.

Prevalence of unmet supportive care needs. More than $80 \%$ of men in the sample had some unmet need across the five domains measured; psychological needs, sexuality needs, and health system and information needs had the greatest prevalence (Table 3). Prostate-specific symptoms were reported by over half the participants: incontinence or dysuria was the most prevalent, followed by hormonal symptoms and then bowel problems (Table 3). Over $45 \%$ of men indicated that they had not seen a nurse at all for one or more dimensions of care during their pathway (Table 4). When men had seen a nurse, support and advice was highest in pre-treatment and immediate treatmentrelated care: over $80 \%$ had received advice and support for screening, diagnosis, side effects and treatment after-care. However, fewer men reported advice and support for longer-term effects, home care, choosing treatment options, referral and emotional support (Table 4).

Predictors of unmet supportive care need. Dimensions of posttreatment nursing care significantly and independently predicted unmet need. The most common aspect was for longer-term effects: men who had not seen a nurse about longer-term effects were twice as likely to have health system and information needs and patient care and support needs. Similarly, men who had not received advice and support from a nurse for longer-term effects were three times as likely to have health system and information needs and patient care and support needs. In addition, men who had not received advice about longer-term effects were twice as likely to have psychological need (Table 5).

Three further areas were significantly associated with unmet need: not seeing a nurse for treatment side effects was associated with psychological need, lack of advice and support for after-care was associated with patient care and support need, and lack of advice and support for home care was associated with sexuality and health system and information need. Nursing care did not predict need in the physical and daily living domain (Table 5). A number of further factors had an impact on unmet needs. The country a man lived in, the stage of his disease and the type of treatment he had experienced were the most common demographic and treatment predictors of unmet need (Table 5). Men in Spain were more likely to have psychological and health system and information needs, and together with men in France, they had a higher probability of sexuality-related needs than men in Denmark (reference category). Men with more extensive disease were more likely to have psychological and health system and information needs and to require help with patient care and support issues. Treatment modality was a significant predictor of unmet need in three respects. Having had chemotherapy was strongly predictive of unmet physical and daily living needs, and having had radical prostatectomy was predictive of unmet sexuality need, whereas men who had had radiotherapy were less likely to have psychological need than men who had not (Table 5).

Men who had finished treatment 1 or more years ago were significantly less likely to have physical and daily living needs compared with men on treatment. The more recently a man had been assessed by a clinician the more likely he was to have health system and information needs, although this was not influenced by time since diagnosis. Conversely, men diagnosed 1-2 months ago were ten times more likely to need help with sexuality issues than men at diagnosis (within the last month) and this changed over time. Neither age nor education nor living status was found to be a significant predictor of unmet need in any domain having included the nursing care variables.

Patient-reported parameters of mental affect and health state were each associated with unmet need for all domains (Table 5). Increasing health state by one unit produced an estimated decrease in odds of reporting need ranging between 1.7 and $4.2 \%$ across domains. Men with moderate or severe anxiety or depression were approximately twice as likely to have sexuality, health system and information, patient care and support or physical and daily living needs, but in line with previous studies, this association was greatly increased in relation to psychological need (odds ratio $=7.604$ ). The questionnaire format was significantly associated with unmet need: men who completed the survey in paper format were less likely than men who had completed it on-line to have unmet psychological physical and daily living needs (Table 5).

\section{DISCUSSION}

This study makes an important contribution to the understanding of the role of supportive care in addressing survivorship needs for men with prostate cancer and the significance of nursing in reducing men's unmet needs. In addition to disease and treatment characteristics, lack of contact with a nurse or advice and support from a nurse was associated with men's unmet needs. The greatest areas of need reflect other survey data (Boberg et al, 2003; Feldman-Stewart et al, 2010; Harrison et al, 2011), which suggest that current services may not be addressing on-going concerns that have an impact on men's long-term distress (Foster et al, 2009; Davies and Batehup, 2011). This provides evidence that access to supportive nursing care can influence patient outcomes, and importantly indicates that there are areas of care, in particular after cancer treatment, that nursing could improve. 


\begin{tabular}{|c|c|c|}
\hline Base & 1001 & $\%$ \\
\hline \multicolumn{3}{|l|}{ Country response } \\
\hline $\begin{array}{l}\text { The Netherlands } \\
\text { UK } \\
\text { Spain } \\
\text { Denmark } \\
\text { France } \\
\text { Ireland } \\
\text { Turkey }\end{array}$ & $\begin{array}{r}319 \\
180 \\
179 \\
125 \\
95 \\
53 \\
50\end{array}$ & $\begin{array}{r}31.9 \\
18.0 \\
17.9 \\
12.5 \\
9.5 \\
5.3 \\
5.0\end{array}$ \\
\hline \multicolumn{3}{|l|}{ Questionnaire format } \\
\hline $\begin{array}{l}\text { On-line } \\
\text { Paper }\end{array}$ & $\begin{array}{l}558 \\
443\end{array}$ & $\begin{array}{l}55.7 \\
44.3\end{array}$ \\
\hline \multicolumn{3}{|l|}{ Age } \\
\hline $\begin{array}{l}50 \text { or less } \\
51-60 \\
61-70 \\
71-80 \\
81+ \\
\text { Total }^{\text {a }}\end{array}$ & $\begin{array}{r}17 \\
142 \\
531 \\
279 \\
31 \\
1000\end{array}$ & $\begin{array}{r}1.7 \\
14.2 \\
53.0 \\
27.9 \\
3.1\end{array}$ \\
\hline \multicolumn{3}{|l|}{ Education } \\
\hline $\begin{array}{l}\text { Finished before } 18 \text { without qualifications } \\
\text { Finished at } 18 \text { with qualifications } \\
\text { Gained a diploma/certificate after } 18 \\
\text { Gained a degree (bachelor's, master's or doctorate) } \\
\text { Total }^{\text {a }}\end{array}$ & $\begin{array}{l}271 \\
274 \\
207 \\
240 \\
992\end{array}$ & $\begin{array}{l}27.3 \\
27.6 \\
20.8 \\
24.1\end{array}$ \\
\hline \multicolumn{3}{|l|}{ Living status } \\
\hline $\begin{array}{l}\text { Living with other (s) } \\
\text { Living alone }\end{array}$ & $\begin{array}{r}907 \\
94\end{array}$ & $\begin{array}{r}90.6 \\
9.4\end{array}$ \\
\hline \multicolumn{3}{|l|}{ Ethnic origin } \\
\hline $\begin{array}{l}\text { White } \\
\text { Black - Caribbean } \\
\text { Black - African } \\
\text { Mixed ethnic origin } \\
\text { Other ethnic group } \\
\text { Prefer not to say } \\
\text { Total }^{\text {a }}\end{array}$ & $\begin{array}{r}975 \\
2 \\
1 \\
1 \\
4 \\
12 \\
995\end{array}$ & $\begin{array}{r}98.0 \\
0.2 \\
0.1 \\
0.1 \\
0.4 \\
1.2\end{array}$ \\
\hline \multicolumn{3}{|l|}{ Time since diagnosis } \\
\hline $\begin{array}{l}\text { Within the last month } \\
1-2 \text { month ago } \\
3-6 \text { months ago } \\
7-12 \text { months ago } \\
1-2 \text { years ago } \\
3-4 \text { years ago } \\
5-10 \text { years ago } \\
\text { More than } 10 \text { years ago } \\
\text { Total }^{\text {a }}\end{array}$ & $\begin{array}{r}24 \\
20 \\
92 \\
120 \\
246 \\
189 \\
237 \\
70 \\
998\end{array}$ & $\begin{array}{r}2.4 \\
2.0 \\
9.2 \\
12.0 \\
24.6 \\
18.9 \\
23.7 \\
7.0\end{array}$ \\
\hline \multicolumn{3}{|l|}{ Stage of prostate cancer } \\
\hline $\begin{array}{l}\text { Stage I } \\
\text { Stage II } \\
\text { Stage III } \\
\text { Stage IV } \\
\text { Don't know/can't remember } \\
\text { Total }\end{array}$ & $\begin{array}{r}112 \\
112 \\
93 \\
63 \\
305 \\
685\end{array}$ & $\begin{array}{r}16.4 \\
16.4 \\
13.6 \\
9.2 \\
44.5\end{array}$ \\
\hline
\end{tabular}

\section{Table 2. (Continued)}

\begin{tabular}{|c|c|c|}
\hline Base & 1001 & $\%$ \\
\hline \multicolumn{3}{|l|}{ Treatment modality ${ }^{b}$} \\
\hline \multicolumn{3}{|l|}{ Received/currently receiving } \\
\hline Prostatectomy & 436 & 43.6 \\
\hline Radiotherapy & 446 & 44.6 \\
\hline Brachytherapy & 99 & 9.9 \\
\hline Hormone therapy & 438 & 43.8 \\
\hline Chemotherapy & 101 & 10.1 \\
\hline High-intensity ultrasound & 16 & 1.6 \\
\hline Active surveillance & 162 & 16.2 \\
\hline Watchful waiting & 122 & 12.2 \\
\hline \multicolumn{3}{|l|}{ Treatment degree } \\
\hline Considering treatment or monitoring & 22 & 2.2 \\
\hline Had a single treatment modality & 398 & 40.1 \\
\hline Had multiple treatment modalities & 573 & 57.7 \\
\hline Total $^{a}$ & 993 & \\
\hline \multicolumn{3}{|l|}{ Treatment status } \\
\hline Considering treatment or monitoring & 22 & 2.2 \\
\hline On treatment & 366 & 36.9 \\
\hline Finished treatment up to 1 year ago & 204 & 20.5 \\
\hline Finished treatment 1 or more years ago & 401 & 40.4 \\
\hline Total $^{a}$ & 993 & \\
\hline \multicolumn{3}{|l|}{ Last assessed by clinician } \\
\hline Within the last year & 657 & 66.8 \\
\hline One year ago & 93 & 9.5 \\
\hline 2 years ago & 64 & 6.5 \\
\hline 3 years ago & 40 & 4.1 \\
\hline $4-13$ years ago & 130 & 13.1 \\
\hline Total $^{a}$ & 984 & \\
\hline \multicolumn{3}{|l|}{ Health state (rating 0-100) } \\
\hline Rated under 50 & 76 & 8.0 \\
\hline Rated 50-74 & 319 & 33.6 \\
\hline Rated 75-100 & 554 & 58.4 \\
\hline Total $^{a}$ & 949 & \\
\hline \multicolumn{3}{|l|}{ Anxiety/depression (mental affect) } \\
\hline Not anxious or depressed & 635 & 66.3 \\
\hline Moderately or extremely depressed & 323 & 33.7 \\
\hline Total ${ }^{a}$ & 958 & \\
\hline
\end{tabular}

Relatively few studies have hitherto researched how supportive nursing intervention can have an impact on men's outcomes after prostate cancer treatment (Ream et al, 2009; Cockle-Hearne and Faithfull, 2010; Chambers et al, 2011; Faithfull et al, 2011; Sussman et al, 2011). Systematic reviews on efficacy of specialised oncology nursing interventions offer evidence that nurse provision leads to improvements in the management of chronic problems and increases patient knowledge and self-management; it can also lead to reduced use of acute services and improve patient symptoms (Corner, 2003; Sussman et al, 2004). Subsequently, nurse-led care and coordination roles have been promoted as an important component of breast cancer services (Eicher et al, 2012) and have been embraced by cancer teams as part of quality care provision (Roselli Del Turco et al, 2010). Strong evidence that the provision of breast cancer clinical nurse specialists has a psychological impact on women has come from randomised trials both during and after treatment. These studies indicate that nurse 
intervention reduces anxiety (Wengstrom et al, 2001; Yates et al, 2005), distress and depression (Strong et al, 2008; Fors et al, 2011) and increases satisfaction in women compared with usual care (Aranda et al, 2006; Beaver et al, 2012). However, in a randomised trial of specialist nursing support for women compared with that provided by a psychologist there were no significant differences in outcome (Arving et al, 2006). This would suggest that it is the quality of contact and/or the intervention targeted against the need, rather than necessarily the role, that has an impact on patient experience. Such a targeted intervention model has been evaluated in Canada with specialist community nurses providing care

Table 3. Prevalence of unmet need

\begin{tabular}{|l|c|c|c|c|}
\cline { 2 - 5 } \multicolumn{1}{c|}{} & \multicolumn{2}{c|}{ No need } & \multicolumn{2}{c|}{ Some need } \\
\hline $\mathbf{N}=1001$ & $\mathbf{n}$ & $\begin{array}{c}\text { \% of } \\
\text { total }\end{array}$ & $\mathbf{n}$ & $\begin{array}{l}\% \text { of } \\
\text { total }\end{array}$ \\
\hline Total need & 186 & 18.6 & 771 & 80.6 \\
\hline
\end{tabular}

Supportive care need domains

\begin{tabular}{|c|c|c|c|c|}
\hline Psychological & 325 & 34.9 & 607 & 65.1 \\
\hline Sexuality & 377 & 39.7 & 573 & 60.3 \\
\hline Health systems and information & 380 & 40.3 & 563 & 59.7 \\
\hline Physical and daily living & 559 & 59.0 & 388 & 41.0 \\
\hline Patient care and support & 566 & 59.3 & 389 & 40.7 \\
\hline \multicolumn{5}{|l|}{ Prostate-specific symptoms } \\
\hline $\begin{array}{l}\text { Urinary incontinence/difficulties in } \\
\text { passing urine }\end{array}$ & 583 & 60.5 & 380 & 39.5 \\
\hline $\begin{array}{l}\text { Hot flushes/feeling as if you are going } \\
\text { through a change of life like women do }\end{array}$ & 644 & 66.3 & 327 & 33.7 \\
\hline $\begin{array}{l}\text { Problems with your bowel habits } \\
\text { Totals exclude missing data }\end{array}$ & 710 & 73.6 & 255 & 26.4 \\
\hline
\end{tabular}

coordination: this led to a marked improvement in patients' unmet supportive care needs (Sussman et al, 2011). Defining the individual dimensions of supportive care required by men in this present study has provided potential targets for cancer nursing intervention within Europe. Fundamental to this is a comprehensive understanding of patient-specific need as an essential precursor to appropriate interventions and for facilitating access to relevant supportive care services as well as training staff to meet those needs (Stricker et al, 2011; Chubak et al, 2012).

It is clear that treatment factors remain important predictors of patient outcome. Men in this study reported higher levels of unmet need in relation to specific treatment modalities, including chemotherapy, which was strongly predictive of need for help with physical and daily living issues, and radical prostatectomy, which was predictive of unmet sexuality needs. Men, who had had radiotherapy, were less likely to have psychological need than men who had not. These unmet needs are consistent with recent prospective clinical studies comparing radiotherapy and prostatectomy; men who underwent radical prostatectomy were five times more likely to have urinary incontinence and twice as likely to have erectile dysfunction at 5 years than those men in the radiotherapy group (Resnick et al, 2013b). Late effects from prostate cancer treatment are often time-dependent and men's lifestyle and co-morbidity can have an impact on rectal, urinary and erectile dysfunction (Thomas et al, 2013). Sexual dysfunction is common in the older population and co-morbidities have an impact on the complexity of predicting erectile problems post treatment (Nelson et al, 2010). It is therefore important to have discussions with men about prevention and possible management of erectile dysfunction before and after therapy (Salonia et al, 2012).

The potential weakness of this study was that it was a 'snap shot' in time of symptoms and unmet needs; it was therefore not possible to differentiate co-morbidities from those of prostate treatment effects. We did not find a relationship between age, education or living status and unmet need, which has been found

Table 4. Dimensions of supportive nursing care

\begin{tabular}{|c|c|c|c|c|c|c|}
\hline \multirow[b]{2}{*}{ Total } & \multicolumn{3}{|c|}{ Did not see a nurse at all } & \multicolumn{3}{|c|}{$\begin{array}{c}\text { When a nurse was seen support anc } \\
\text { advice received }\end{array}$} \\
\hline & & 1001 & $\%$ & & 1001 & $\%$ \\
\hline Advice about screening & $\begin{array}{l}\text { Did not see a nurse } \\
\text { Total }^{a}\end{array}$ & $\begin{array}{l}421 \\
931\end{array}$ & 45.2 & $\begin{array}{l}\text { Had support } \\
\text { Total }^{\mathbf{b}}\end{array}$ & $\begin{array}{l}426 \\
510\end{array}$ & 83.5 \\
\hline Information and support at the time of diagnosis & $\begin{array}{l}\text { Did not see a nurse } \\
\text { Total }^{\mathrm{a}}\end{array}$ & $\begin{array}{l}303 \\
919\end{array}$ & 33.0 & $\begin{array}{l}\text { Had support } \\
\text { Total }^{\mathbf{b}}\end{array}$ & $\begin{array}{l}515 \\
616\end{array}$ & 83.6 \\
\hline Help choosing treatment options & $\begin{array}{l}\text { Did not see a nurse } \\
\text { Totala }^{a}\end{array}$ & $\begin{array}{l}415 \\
897\end{array}$ & 46.3 & $\begin{array}{l}\text { Had support } \\
\text { Total }^{\mathbf{b}}\end{array}$ & $\begin{array}{l}320 \\
482\end{array}$ & 66.4 \\
\hline Provided enough immediate care after treatment & $\begin{array}{l}\text { Did not see a nurse } \\
\text { Total }^{a}\end{array}$ & $\begin{array}{l}198 \\
962\end{array}$ & 20.6 & $\begin{array}{l}\text { Had support } \\
\text { Total }^{\mathbf{b}}\end{array}$ & $\begin{array}{l}683 \\
764\end{array}$ & 89.4 \\
\hline Information and advice about side effects that occur after treatment & $\begin{array}{l}\text { Did not see a nurse } \\
\text { Total }^{a}\end{array}$ & $\begin{array}{l}284 \\
935\end{array}$ & 30.4 & $\begin{array}{l}\text { Had support } \\
\text { Total }\end{array}$ & $\begin{array}{l}524 \\
651\end{array}$ & 80.5 \\
\hline Information, advice and support about longer-term side effects & $\begin{array}{l}\text { Did not see a nurse } \\
\text { Total }^{\mathrm{a}}\end{array}$ & $\begin{array}{l}432 \\
926\end{array}$ & 46.7 & $\begin{array}{l}\text { Had support } \\
\text { Total }^{\mathbf{b}}\end{array}$ & $\begin{array}{l}307 \\
494\end{array}$ & 62.1 \\
\hline Gave emotional support to me and/or my family and friends & $\begin{array}{l}\text { Did not see a nurse } \\
\text { Total }^{\mathrm{a}}\end{array}$ & $\begin{array}{l}378 \\
956\end{array}$ & 39.5 & $\begin{array}{l}\text { Had support } \\
\text { Total }^{\mathbf{b}}\end{array}$ & $\begin{array}{l}436 \\
626\end{array}$ & 69.6 \\
\hline Referral to other services & $\begin{array}{l}\text { Did not see a nurse } \\
\text { Total }^{a}\end{array}$ & $\begin{array}{l}533 \\
952\end{array}$ & 56.0 & $\begin{array}{l}\text { Had support } \\
\text { Total }^{\mathbf{b}}\end{array}$ & $\begin{array}{l}239 \\
419\end{array}$ & 57.0 \\
\hline Advice about home care & $\begin{array}{l}\text { Did not see a nurse } \\
\text { Total }^{\text {a }}\end{array}$ & $\begin{array}{l}523 \\
956\end{array}$ & 54.7 & $\begin{array}{l}\text { Had support } \\
\text { Total }^{\mathbf{b}}\end{array}$ & $\begin{array}{l}286 \\
433\end{array}$ & 66.1 \\
\hline
\end{tabular}




\begin{tabular}{|c|c|c|c|c|c|}
\hline Domain & Predictor & Estimate $^{a}$ & $\begin{array}{l}\text { Standard } \\
\text { error }^{a}\end{array}$ & $P$-value ${ }^{a}$ & $\begin{array}{l}\text { Odds ratio }{ }^{\mathrm{a}}(95 \% \\
\text { confidence interval) }\end{array}$ \\
\hline \multirow[t]{11}{*}{ Psychological } & Country (reference: Denmark) & - & - & - & - \\
\hline & $\begin{array}{l}\text { France } \\
\text { Ireland } \\
\text { The Netherlands } \\
\text { Spain } \\
\text { Turkey } \\
\text { UK }\end{array}$ & $\begin{array}{r}-0.377 \\
0.701 \\
0.006 \\
1.539 \\
0.426 \\
-0.390\end{array}$ & $\begin{array}{l}0.649 \\
0.614 \\
0.484 \\
0.446 \\
0.675 \\
0.533\end{array}$ & $\begin{array}{l}0.561 \\
0.253 \\
0.990 \\
0.001 \\
0.528 \\
0.464\end{array}$ & $\begin{array}{c}0.686(0.192,2.447) \\
2.016(0.605,6.716) \\
1.006(0.390,2.598) \\
4.658(1.942,11.170) \\
1.531(0.407,5.751) \\
0.677(0.238,1.923)\end{array}$ \\
\hline & Stage (reference: Stage I) & - & - & - & - \\
\hline & $\begin{array}{l}\text { Stage } 2 \\
\text { Stage } 3 \\
\text { Stage } 4 \\
\text { Do not know; cannot remember }\end{array}$ & $\begin{array}{l}1.166 \\
1.095 \\
1.168 \\
0.785\end{array}$ & $\begin{array}{l}0.364 \\
0.404 \\
0.497 \\
0.309\end{array}$ & $\begin{array}{l}0.001 \\
0.007 \\
0.019 \\
0.011\end{array}$ & $\begin{array}{l}3.209(1.573,6.548) \\
2.988(1.353,6.599) \\
3.216(1.214,8.515) \\
2.192(1.196,4.019)\end{array}$ \\
\hline & Receiving/received radiotherapy(reference: not had) & -0.471 & 0.232 & 0.043 & $0.625(0.396,0.985)$ \\
\hline & Mental affect (reference: not anxious or depressed) & - & - & - & - \\
\hline & Moderately/extremely anxious or depressed & 2.029 & 0.323 & $<0.001$ & $7.604(4.037,14.325)$ \\
\hline & Health state & -0.040 & 0.008 & $<0.001$ & $0.961(0.945,0.976)$ \\
\hline & Nursing care (reference: had advice and support) & - & - & - & - \\
\hline & $\begin{array}{l}\text { No nurse advice for treatment side effects } \\
\text { No nurse contact for treatment side effects } \\
\text { No nurse advice for longer-term effects } \\
\text { No nurse contact for longer-term effects }\end{array}$ & $\begin{array}{r}0.124 \\
0.912 \\
0.747 \\
-0.050\end{array}$ & $\begin{array}{l}0.366 \\
0.315 \\
0.344 \\
0.293\end{array}$ & $\begin{array}{l}0.735 \\
0.004 \\
0.030 \\
0.865\end{array}$ & $\begin{array}{l}1.132(0.553,2.319) \\
2.490(1.343,4.616) \\
2.111(1.076,4.144) \\
0.951(0.536,1.690)\end{array}$ \\
\hline & Paper format (reference: on-line) & -0.914 & 0.379 & 0.016 & $0.401(0.191,0.842)$ \\
\hline \multirow[t]{10}{*}{ Sexuality } & Country (reference: Denmark) & - & - & - & - \\
\hline & $\begin{array}{l}\text { France } \\
\text { Ireland } \\
\text { The Netherlands } \\
\text { Spain } \\
\text { Turkey } \\
\text { UK }\end{array}$ & $\begin{array}{r}0.748 \\
0.093 \\
-0.070 \\
1.144 \\
0.330 \\
-0.328\end{array}$ & $\begin{array}{l}0.355 \\
0.375 \\
0.243 \\
0.307 \\
0.457 \\
0.260\end{array}$ & $\begin{array}{r}0.035 \\
0.803 \\
0.774 \\
<0.001 \\
0.470 \\
0.208\end{array}$ & $\begin{array}{l}2.112(1.053,4.235) \\
1.098(0.526,2.291) \\
0.933(0.579,1.502) \\
3.138(1.720,5.727) \\
1.391(0.568,3.406) \\
0.720(0.432,1.200)\end{array}$ \\
\hline & Time since diagnosis (reference: within last month) & - & - & - & - \\
\hline & $\begin{array}{l}1-2 \text { months } \\
3-6 \text { months } \\
7-12 \text { months } \\
1-2 \text { years } \\
3-4 \text { years } \\
5-10 \text { years } \\
\text { More than } 10 \text { years }\end{array}$ & $\begin{array}{l}2.322 \\
0.974 \\
1.028 \\
0.782 \\
0.802 \\
0.625 \\
0.686\end{array}$ & $\begin{array}{l}0.960 \\
0.618 \\
0.602 \\
0.585 \\
0.589 \\
0.581 \\
0.624\end{array}$ & $\begin{array}{l}0.016 \\
0.115 \\
0.088 \\
0.182 \\
0.174 \\
0.282 \\
0.272\end{array}$ & \begin{tabular}{|c|}
$10.199(1.553,66.955)$ \\
$2.649(0.788,8.901)$ \\
$2.796(0.857,9.127)$ \\
$2.186(0.693,6.897)$ \\
$2.230(0.702,7.085)$ \\
$1.869(0.597,5.850)$ \\
$1.986(0.583,6.758)$ \\
\end{tabular} \\
\hline & Receiving/received prostatectomy (reference: not had) & 0.453 & 0.160 & 0.005 & $1.573(1.150,2.153)$ \\
\hline & Mental affect (reference: not anxious or depressed) & - & - & - & - \\
\hline & Moderately/extremely anxious or depressed & 0.560 & 0.183 & 0.002 & $1.751(1.225,2.505)$ \\
\hline & Health state & -0.022 & 0.005 & $<0.001$ & $0.978(0.969,0.988)$ \\
\hline & Nursing care (reference: had advice and support) & - & - & - & - \\
\hline & $\begin{array}{l}\text { No nurse advice about home care } \\
\text { No nurse contact about home care }\end{array}$ & $\begin{array}{l}0.734 \\
0.105\end{array}$ & $\begin{array}{l}0.260 \\
0.187\end{array}$ & $\begin{array}{l}0.005 \\
0.574\end{array}$ & $\begin{array}{l}2.083(1.252,3.466) \\
1.111(0.770,1.605)\end{array}$ \\
\hline \multirow[t]{7}{*}{ Patient care and support } & Stage (reference: Stage I) & - & - & - & - \\
\hline & $\begin{array}{l}\text { Stage } 2 \\
\text { Stage } 3 \\
\text { Stage } 4 \\
\text { Do not know/cannot remember }\end{array}$ & $\begin{array}{l}0.691 \\
0.502 \\
0.663 \\
0.485\end{array}$ & $\begin{array}{l}0.335 \\
0.357 \\
0.406 \\
0.284\end{array}$ & $\begin{array}{l}0.039 \\
0.160 \\
0.103 \\
0.088\end{array}$ & $\begin{array}{l}1.997(1.035,3.850) \\
1.652(0.820,3.329) \\
1.940(0.875,4.303) \\
1.624(0.930,2.836)\end{array}$ \\
\hline & Mental affect (reference: not anxious or depressed) & - & - & - & - \\
\hline & Moderately/extremely anxious or depressed & 1.038 & 0.220 & $<0.001$ & $2.823(1.833,4.348)$ \\
\hline & Health state & -0.019 & 0.006 & 0.002 & $0.981(0.969,0.993)$ \\
\hline & Nursing care (reference: had advice and support) & - & - & - & - \\
\hline & $\begin{array}{l}\text { No nurse advice for after-care } \\
\text { No nurse contact for after-care } \\
\text { No nurse advice for longer-term effects } \\
\text { No nurse contact for longer-term effects }\end{array}$ & $\begin{array}{l}1.614 \\
0.153 \\
0.995 \\
0.571\end{array}$ & $\begin{array}{l}0.395 \\
0.263 \\
0.278 \\
0.234\end{array}$ & $\begin{array}{r}<0.001 \\
0.560 \\
<0.001 \\
0.015\end{array}$ & $\begin{array}{c}5.020(2.316,10.882) \\
1.166(0.696,1.953) \\
2.706(1.570,4.664) \\
1.770(1.119,2.800)\end{array}$ \\
\hline
\end{tabular}




\section{Table 5. (Continued)}

\begin{tabular}{|c|c|c|c|c|c|}
\hline Domain & Predictor & Estimate $^{a}$ & $\begin{array}{c}\text { Standard } \\
\text { error }^{a}\end{array}$ & $P$-value ${ }^{a}$ & $\begin{array}{l}\text { Odds ratio }(95 \% \\
\text { confidence interval) }\end{array}$ \\
\hline \multirow[t]{21}{*}{ Health system and information } & Country (reference: Denmark) & - & - & - & - \\
\hline & France & 0.421 & 0.479 & 0.380 & $1.523(0.595,3.898)$ \\
\hline & Ireland & -0.380 & 0.540 & 0.481 & $0.684(0.237,1.970)$ \\
\hline & The Netherlands & -0.153 & 0.362 & 0.672 & $0.858(0.422,1.744)$ \\
\hline & Spain & 1.325 & 0.448 & 0.003 & $3.764(1.563,9.067)$ \\
\hline & Turkey & 0.483 & 0.627 & 0.441 & $1.621(0.474,5.542)$ \\
\hline & UK & 0.071 & 0.386 & 0.854 & $1.074(0.503,2.289)$ \\
\hline & Stage (reference: Stage I) & - & - & - & - \\
\hline & Stage 2 & 0.788 & 0.334 & 0.018 & $2.199(1.142,4.236)$ \\
\hline & Stage 3 & 1.220 & 0.369 & 0.001 & $3.389(1.645,6.979)$ \\
\hline & Stage 4 & 1.169 & 0.451 & 0.010 & $3.219(1.330,7.791)$ \\
\hline & Do not know/cannot remember & 0.734 & 0.280 & 0.009 & $2.083(1.203,3.607)$ \\
\hline & Time since last assessed & -0.130 & 0.044 & 0.004 & $0.878(0.805,0.958)$ \\
\hline & Mental affect (reference: not anxious or depressed) & - & - & - & - \\
\hline & Moderately/extremely anxious or depressed & 1.000 & 0.253 & $<0.001$ & $2.718(1.654,4.465)$ \\
\hline & Health state & -0.017 & 0.007 & 0.012 & $0.983(0.970,0.996)$ \\
\hline & Nursing care (reference: had advice and support) & - & - & - & - \\
\hline & No nurse advice for longer-term effects & 1.264 & 0.318 & $<0.001$ & $3.539(1.899,6.596)$ \\
\hline & No nurse contact for longer-term effects & 0.937 & 0.255 & $<0.001$ & $2.553(1.549,4.205)$ \\
\hline & No nurse advice about home care & 1.018 & 0.354 & 0.004 & $2.769(1.383,5.544)$ \\
\hline & No nurse contact about home care & 0.130 & 0.259 & 0.615 & $1.139(0.686,1.892)$ \\
\hline \multirow[t]{8}{*}{ Physical and daily living } & Receiving/received chemotherapy (reference: not had) & 1.716 & 0.316 & $<0.001$ & $5.561(2.995,10.324)$ \\
\hline & Treatment status (reference: on treatment) & - & - & - & - \\
\hline & Finished treatment up to 1 year ago & 0.260 & 0.215 & 0.226 & $1.296(0.851,1.974)$ \\
\hline & Finished treatment 1 or more years ago ${ }^{b}$ & -0.489 & 0.185 & 0.008 & $0.613(0.427,0.881)$ \\
\hline & Mental affect (reference: had advice and support) & - & - & - & - \\
\hline & Moderately/extremely anxious or depressed & 0.866 & 0.170 & $<0.001$ & $2.377(1.704,3.315)$ \\
\hline & Health state & -0.043 & 0.005 & $<0.001$ & $0.958(0.948,0.968)$ \\
\hline & Paper format (reference: on-line) & -0.489 & 0.165 & 0.003 & $0.614(0.444,0.848)$ \\
\hline \multicolumn{6}{|c|}{$\begin{array}{l}\text { Based on observed data: psychological domain specificity } 57.9 \% \text {, sensitivity } 85.7 \% \text { Youden index } 0.436 \text {; sexuality domain specificity } 51.6 \% \text { sensitivity } 78.2 \% \text { Youden index } 0.564 ; \text { health system } \\
\text { and information domain specificity } 55.0 \% \text { sensitivity } 82.5 \% \text { Youden index } 0.375 \text {; patient care and support domain specificity } 81.4 \% \text { sensitivity } 50.2 \% \text { Youden index } 0.316 \text {; physical and daily living } \\
\text { domain specificity } 84.1 \% \text { sensitivity } 58.4 \% \text { Youden index } 0.425 \text {. } \\
\text { a pooled multiple imputation results. }\end{array}$} \\
\hline
\end{tabular}

in other studies (Steginga et al, 2001; Lintz et al, 2003; Smith et al, 2007; Ream et al, 2008). However, living in Spain was associated with a higher probability of unmet sexuality, psychological and health system and information need, and living in France was also associated with a higher probability of unmet sexuality need. This may be the result of differing cultural expectations in relation to sexual attitudes in these two countries. Men with cancer are less likely than women to recognise the need for help because of cultural and societal barriers especially in relation to sexual issues (Courtenay, 2000; Tamres et al, 2002; Hautamaki-Lamminen et al, 2013). It should also be emphasised that the association of unmet need with the country of residence in this study was independent of the effect of supportive nursing care as measured.

An important theme emerging from the analysis was the lack of support for on-going symptoms and concerns after treatment and their association with unmet need. Evidence from a recent patientreported outcome study within the United Kingdom (DoH, 2012) suggested information and preparation for cancer follow-up is limited. Patients described being 'cut adrift' by the health system after active therapy (Corner et al, 2013). Patient satisfaction with health-care provision is an important measure in assessing the structure and process of cancer care, and is associated with reduced quality-of-life including decline in post-treatment physical function (Resnick et al, 2013a). In this present study, recent assessment by a clinician and being a year or more out of treatment were significant predictors of unmet need, indicating that clinician contact paradoxically did not always address men's needs. This is also confirmed in a longitudinal study of patients after cancer treatment, despite follow-up checks over $30 \%$ of patients, who had symptoms at the end of therapy, continued to experience such symptoms 12 months later (Armes et al, 2009). Providing longterm care for prostate cancer patients has been reported as challenging especially in primary care (Zhou et al, 2010). In the United States of America, studies have shown that only a minority of physicians feel able to manage the consequences of cancer treatment (McCabe et al, 2011; Skolarus et al, 2011; Chubak et al, 2012). Oncologists in the UK have also shown concern that primary care doctors have little experience of follow-up and longer-term effects of prostate cancer treatment (Watson et al, 2011). The predictive model in this study shows that unmet need can change over time in that men were much more likely to need help with sexuality issues when they had been recently diagnosed; however, as stage of disease progressed, unmet psychological, patient care and information needs remained. 
Despite this being the first study in Europe to examine the relationship of supportive nursing care to patients' unmet needs, and the comparatively successful response to the survey, there are strengths and weaknesses. In using the SCNS, we have examined some need $v s$ no need; in contrast, some studies have categorised only moderate-to-severe need (Armes et al, 2009). We believe that it is important for defining supportive care packages to consider the range of unmet need since, if not supported, low need can become moderate or even high need at a later stage. A further strength of this study is that it is based on the more sensitive measurement of unmet need, that is, assessing where help is needed, rather than on quality-of-life, which in this population may not consistently differentiate from the norm. A limitation with the SCNS is that it has been validated for paper and electronic administration via touch-screen computer (Boyes et al, 2002), but not currently for on-line use. There is evidence from this study that the tool could perform differently on psychological and physical and daily living domains when administered on-line: the statistical modelling indicated that men who completed the paper version were significantly less likely to have unmet need in these domains than men who completed the survey via the internet. This difference in performance is unlikely to be the result of format selection bias, as choice of format in this survey was not given at the point of completion. However, there may have been some bias in the clinic setting where paper was more easy to complete. Further research would need to clarify this variation in the tool. A potential limitation of this study is that the outcomes are based on reported measures of nursing care, rather than on observed practice. However, the patient perspective is important in that it tells us what patients value in managing their care, and this is a crucial aspect to incorporate in evaluating cancer services within a patient-centred care framework (Velikova et al, 2002; Luckett et al, 2009).

A fundamental shift is required in survivorship care to improve outcomes for men with prostate cancer, especially after treatment is completed. Furthermore, more consistent provision of nurses across the care pathway, with training to address sexual dysfunction and psychological care, should be a priority for enhancing supportive care. The provision of information, symptom management and long-term side effects are areas in need of improvement. Recognition of specialist nurses within cancer multidisciplinary teams is not consistent across Europe and their inclusion should be essential in defining quality prostate cancer care. As the population of men increases, so will the need for monitoring and management. Whether after-care is received from oncology, urology or primary care, it is important that all healthcare professionals recognise the extent of long-term consequences experienced by cancer patients. Health-care services therefore need to provide effective and targeted supportive care for men after prostate cancer treatment to meet this growing population of survivors.

\section{ACKNOWLEDGEMENTS}

We would like to thank the patient groups who circulated information about this research and the men across the seven countries who completed the survey. We would also like to thank EONS for their valuable comments and organisational support.

\section{CONFLICT OF INTEREST}

The authors declare no conflict of interest.

\section{AUTHOR CONTRIBUTIONS}

JC-H and SF conceived the design of the study and acquisition of the data. JC-H, SF, DK, FC-S, LD, HEF and BTJ were responsible for the design and analysis of the study. JC-H, KL, EvM, FC-S, PF-O, BTJ and SK were responsible for undertaking data collection within their respective European countries. The initial draft of the paper was produced by JC-H, HEF and SF, and circulated between all authors for critical revision. All authors read and approved the final manuscript.

\section{ETHICS APPROVAL}

This work was reviewed in the UK by the South East Coast Surrey Research Ethics Committee (Rec Ref 11/LO/0738) and approval given on 8 June 2011.

\section{FUNDING}

This research was funded by a grant to the University of Surrey from The European Oncology Nursing Society (EONs) as part of the Prostate Cancer Education Project (PrEP).

\section{REFERENCES}

Aranda S, Schofiled P, Weih Lea (2006) Meeting the support and information needs of women with advanced breast cancer: a randomised controlled trial. Br J Cancer 95(6): 667-673.

Armes J, Crowe M, Colbourne L, Morgan H, Murrells T, Oakley C, Palmer N, Ream E, Young A, Richardson A (2009) Patients' supportive care needs beyond the end of cancer treatment: a prospective, longitudinal survey. J Clin Oncol 27(36): 6172-6179.

Arving C, Sjoden P, Bergh Jea (2006) Satisfaction, utilisation and perceived benefit of individual psychosocial support for breast cancer patients- a randomised study of nurse versus psychologist interventions. Patient Educ Couns 62(2): 235-243.

Beaver K, Campbell M, Williamson S, Procter D, Sheridan J, Heath J, Susnerwala S (2012) An exploratory randomized controlled trial comparing telephone and hospital follow-up after treatment for colorectal cancer. Colorectal Dis 14(10): 1201-1209.

Berrino F, de Angelis R, Sant M, Rosso S, Lasota M, Coebergh J, Santaquilani M (2007) Survival for eight major cancers and all cancers combined for European adults diagnosed in 1995-99 results of the EUROCARE-4 study. Lancet Oncol 8: 773-783.

Boberg EW, Gustafson DH, Hawkins RP, Offord KP, Kock C, Wen K-Y, Kreutz K, Salner A (2003) Assessing the unmet information, support and care delivery needs of men with prostate cancer. Patient Educ Couns 49: 233-242.

Boyes A, Girgis A, Lecathelinais C (2009) Brief assessment of adult cancer patients' perceived needs: development and validation of the 34 -item Supportive Care Needs Survey (SCNS-SF34). J Eval Clin Pract 15(4): 602-606.

Boyes A, Newell S, Girgis A (2002) Rapid assessment of psychosocial well-being: are computers the way forward in a clinical setting? Qual Life Res 11(1): 27-35.

Chambers S, Pinnock C, Lepore S, Hughes S, O'Connell D (2011) A systematic review of psychosocial interventions for men with prostate cancer and their partners. Patient Educ Couns 85(2): e75-e88.

Chubak J, Tuzzio L, Hsu C, Alfano CM, Rabin BA, Hornbrook MC, Spegman A, Von Worley A, Williams A, Nekhlyudov L (2012) Providing care for cancer survivors in integrated health care delivery systems: practices, challenges, and research opportunities. J Oncol Pract 8(3): 184-189.

Cockle-Hearne J, Faithfull S (2010) Self-management for men surviving prostate cancer: a review of behavioural and psychosocial interventions to understand what strategies can work, for whom and in what circumstances. Psycho-Oncology 19(9): 909-922.

Corner J (2003) The role of nurse-led care in cancer management. Lancet Oncol 4(10): 631-636. 
Corner J, Wagland R, Glaser A, Richards M (2013) Qualitative analysis of patients' feedback from a PROMs survey of cancer patients in England. BMJ Open 3: e002316.

Courtenay W (2000) Constructions of masculinity and their influence on men's well being: a theory of gender and health. Soc Sci Med 50(10): 1385.

Davies N, Batehup L (2011) Towards a personalised approach to aftercare: a review of cancer follow up in the UK. J Cancer Surviv 5: 142-151.

DoH (2012) Quality of life of cancer survivors in England: Report on a pilot survey using Patient Reported Outcome Measures (PROMS).

Eicher M, Kadmon I, Claassen S, Marquard S, Pennery E, Wengstrom Y, Fenlon D (2012) Training breast care nurses throughout Europe: the EONS postbasic curriculum for breast cancer nursing. Eur J Cancer 48 : 1257-1262.

Elliott J, Fallows A, Staetsky L, Smith P, Foster C, Maher E, Corner J (2011) The health and well-being of cancer survivors in the UK: findings from a population survey. Br J Cancer 105: S11-S20.

Faithfull S, Cockle-Hearne J, Khoo V (2011) Self-management after prostate cancer treatment: evaluating the feasibility of providing a cognitive and behavioural programme for lower urinary tract symptoms. BJU Int 107(5): 783-790.

Feldman-Stewart D, Capirci C, Brennenstuhl S, Tong C, Abacioglu U, Gawkowska-Suwinsk. M, van Gils F, Heyda A, Igdem S, Macias V, Grillo I, Moynihan C, Pijls-Johannesma M, Parker C, Pimentel N, Wordehoff H (2010) Information needs of early-stage prostate cancer patients: a comparison of nine countries. Radiother Oncol 94(3): 328-333.

Fors E, Bertheussen G, Thune I, Juvet L, Elvsaas I, Oldervoll L, Anker G, Falkmer U, Lundgren S, Leivseth G (2011) Psychosocial interventions as part of breast cancer rehabilitation programs? Results from a systematic review. Psychooncology 20(9): 909-918.

Foster C, Wright D, Hill H, Hopkinson J, Roffe L (2009) Psychosocial implications of living 5 years or more following a cancer diagnosis: a systematic review of the research evidence. Eur J Cancer Care (Engl) 18(3): 223-247.

Harrison J, Young J, Price M, Butow P, Solomon M (2009) What are the unmet supportive care needs of people with cancer? A systematic review. Support Care Cancer 17(8): 1117-1128.

Harrison SE, Watson EK, Ward AM, Khan NF, Turner D, Adams E, Forman D, Roche MF, Rose PW (2011) Primary health and supportive care needs of long-term cancer survivors: a questionnaire survey. J Clin Oncol 29(15): 2091-2098.

Hautamaki-Lamminen K, Lipiainen L, Beaver K, Lehto J, KellokumpuLehtinen P (2013) Identifying patients with greater need for information about sexual issues. Eur J Oncol Nurs 17: 9-15.

Higano CS (2012) Sexuality and intimacy after definitive treatment and subsequent androgen deprivation therapy for prostate cancer. J Clin Oncol 30(30): 3720-3725.

Jacobsen PB, Holland JC, Steensma DP (2012) Caring for the whole patient: the science of psychosocial care. J Clin Oncol 30(11): 1151-1153.

Kenfield S, Stamper M, Giovannucci E, Chan J (2011) Physical activity and survivial after prostate cancer diagnsois in the health professionals followup study. J Clin Oncol 29(6): 726-732.

Khan N, Mant D, Carpenter L, Forman D, Rose P (2011) Long term health outcomes in a British cohort of breast, colorectal and prostate cancer survivors a database study. Br J Cancer 105: S29-S53.

Lintz K, Moynihan C, Steginga S, Norman A, Eeles R, Huddert R, Dearnaley D, Watson M (2003) Prostate cancer patients' support and psychological care needs: survey from a non-surgical oncology clinic. Psychooncology 12: 769-783.

Luckett T, Butow P, King M (2009) Improving patient outcomes through the routine use of patient-reported data in cancer clinics: future directions. Psychooncology 18(11): 1129-1138.

Lustberg MB, Reinbolt RE, Shapiro CL (2012) Bone health in adult cancer survivorship. J Clin Oncol 30(30): 3665-3674.

McCabe M, Baker S, Huffman C, Miller K (2011) Optimizing survivorship care: academic and community clinic models. In Health Services for Cancer Survivors, Feurstein M, Ganz P (eds) (Springer: New York, USA).

Nelson C, Deveci S, Stasi J, Scardino P, Mulhall J (2010) Sexual bother following radical prostatectomy. J Sex Med 7: 129-135.

Pachman DR, Barton DL, Swetz KM, Loprinzi CL (2012) Troublesome symptoms in cancer survivors: fatigue, insomnia, neuropathy, and pain. J Clin Oncol 30(30): 3687-3696.

Pickard A, Wilke C, Lin H, Lloyd A (2007) Health utilities using the EQ-5D in studies of cancer. Pharmacoeconomics 25(5): 365-384.
Ream E, Quennell A, Fincham L, Faithfull S, Khoo V, Wilson-Barnett J, Richardson A (2008) Supportive care needs of men living with prostate cancer in England: a survey. Br J Cancer 98(12): 1903-1909.

Ream E, Wilson-Barnett J, Faithfull S, FIncham L, Khoo V, Richardson A (2009) Working patterns and perceived contribution of prostate cancer clinical nurse specialists: a mixed method investigation. Int J Nurs Stud $\mathbf{4 6}$ : $1345-1354$.

Resnick M, Guzzo T, Cowan J, Knight S, Carroll P, Penson D (2013a) Factors associated with satisfaction with prostate cancer care: results from Cancer of the Prostate Strategic Urologic Research Endeavor (CaPSURE). BJU Int 111(2): 213-220.

Resnick M, Koyaama T, Fan KH, Albertson P, Goodman M, Hamilton A, Hoffman R, Potosky A, Stanford J, Stroup A, Van Horn R, Penson D (2013b) Long-term functional outcomes after treatment for localized prostate cancer. N Engl J Med 368(5): 436-445.

Roselli Del Turco M, Ponti A, Bick U (2010) Quality indicators in breast cancer care. Eur J Cancer 46(13): 2344-2356.

Salonia A, Burnett A, Graefen M, Hatzimouratidis K, Monorsi F, Mulhall J, Steif C (2012) Prevention and management of postprostatectomy sexual dysfunction part 1: choosing the right patient at the right time for the right surgery. Eur Urol 62(2): 261-272.

Seklehner S, Hladschik-Kermer B, Lusuardi L, Schabauer C, Riedl C, Engelhardt P (2012) Psychological stress assessment of patients suffering from prostate cancer. Scand J Urol Nephrol 47(2): 101-107.

Siegel R, Naishadham D, Jemal A (2012) Cancer statistics. CA Cancer J Clin 62(1): 10-29.

Simonelli C, Annunziata MA, Chimienti E, Berretta M, Tirelli U (2008) Cancer survivorship: a challenge for the European oncologists. Ann Onc 19(7): 1216-1217.

Skolarus T, Homes-Rovner M, Northouse L, Fagerlin A, Garlinhouse C, Demers R, Rovner D, Darwish-Yassine M, Wei J (2011) Primary care perspectives on prostate cancer survivorship: implications for improving quality of care. Urol Oncol 31: 727-732.

Smith D, Supramaniam R, King M, Ward J, Berry M, Armstrong B (2007) Age, health and education determine supportive care needs of men younger than 70 years with prostate cancer. J Clin Oncol 25: 2560-2566.

Stanton AL (2012) What happens now? Psychosocial care for cancer survivors after medical treatment completion. J Clin Oncol 30(11): 1215-1220.

Steginga S, Occhipinti S, Dunn J, Gardiner R, Heathcote P, Yaxley J (2001) The supportive care needs of men with prostate cancer. Psycho-oncology 10: $66-75$.

Stricker C, Jacobs L, Risendal B, Jones A, Panzer S, Ganz P, Syrjala K, McCabe M, Baker K, Miller K, Casillas J, Rosenstein D, Campbell M, Palmer S (2011) Survivorship care planning after the institute of medicine recommendations: how are we faring? J Cancer Surviv 5(4): 358-370.

Strong V, Waters R, Hibberd Cea (2008) Management of depression for people with cancer (SMaRT Oncology 1): a randomised study. Lancet 372(9632): 40-48.

Sussman J, Howell D, Bainbridge D, Brazil K, Pyette N, Abbasi S, Whelan T (2011) The impact of specialized oncology nursing on patient supportive care outcomes. J Psychosoc Oncol 29(3): 286-307.

Sussman J, Howell D, O'Brien MA, Whelan T, Pyette N, Bainbridge D, Wienikowski J (2004) An evaluation of the effectiveness of a specialized nurse case management model in coordinating supportive cancer care in the community Toronto, Canada: Ontario Ministry of Health and Long Term Care.

Svende A, Williams A (2004) Measuring self reported population health: an international perspective based on EQ5D: EuroQol Group.

Tamres L, Janicke D, Helgeson V (2002) Sex differences in coping behavior: a meta analytic review and an examination of relative coping. Perc Soc Psychol Rev 6: 2-30.

Thomas R, Holm M, Williams M, Bowman E, Bellamy P, Andreyev J, Maher J (2013) Lifestyle factors correlate with the risk of late pelvic symptoms after prostate radiotherapy. Clin Oncol 25: 246-251.

Van Hemelrijck M, Garmo H, Holmberg L, Ingelsson E, Bratt O, Bill-Axelson A, Lambe M, Stattin P, Adolfsson J (2010) Absolute and relative risk of cardiovascular disease in men with prostate cancer: results from the population-based PCBaSe Sweden. J Clin Oncol 28(21): 3448-3456.

Velikova G, Brown J, Smith A, Selby P (2002) Computer-based quality of life questionnaires may contribute to doctor-patient interactions in oncology. Br J Cancer 86(1): 51-59. 
Watson E, O'Brien R, Campbell C, Weller D, Neal RD, Wilkinson C, Rose PW. Group obotPCF-US (2011) Views of health professionals on the role of primary care in the follow-up of men with prostate cancer. Fam Pract 28(6): 647-654.

Wengstrom Y, Haggmark C, Forberg C (2001) Coping with radiation therapy: effects of nursing intervention on coping ability for women with breast cancer. In J Nurs Pract 7(1): 8-15.

White K, D'Abrew N, Katris P, O'Connor M, Emery L (2012) Mapping the psychosocial and practical support needs of cancer patients in Western Australia. Eur J Cancer Care 21(1): 107-116.

Yates P, Aranda S, Hargraves M, Mirolo B, Clavarino A, McLachlan S, Skerman H (2005) Randomized controlled trial of an educational intervention for managing fatigue in women receiving adjuvant chemotherapy for early-stage breast cancer. J Clin Oncol 23(25): 6027-6038.

Zhou E, Penedo F, Bustillo Nea (2010) Longitudinal effects of social support and adapative coping on the emotional well-being of survivors of localized prostate cancer. J Support Oncol 8(5): 196-201.

(c) (1) (2) (2) This work is licensed under the Creative Commons Attribution-NonCommercial-Share Alike 3.0 Unported License. To view a copy of this license, visit http://creativecommons. org/licenses/by-nc-sa/3.0/ 